\title{
Acute Respiratory Distress Syndrome and Myocarditis Caused by Human Metapneumovirus in a Child
}

\section{Çocukta İnsan Metapneumovirüs'ün Neden Olduğu Akut Solunum Sıkıntısı Sendromu ve Miyokardit}

\author{
(i) Kahraman YAKUT, io Birgül VARAN, id İlkay ERDOĞAN, iD Kürşad TOKEL
}

Başkent University Faculty of Medicine, Department of Pediatric Cardiology, Ankara, Turkey

\begin{abstract}
Human metapneumovirus (hMPV), a recently described paramyxovirus, has commonly been associated with upper and lower respiratory tract infections in young children. Severe infections including cardiovascular disease associated with hMPV have been particularly reported in older and immunocompromised patients; however, there has been no previous report of hMPV causing myocarditis in a child. In this article, we present a rare case with acute respiratory distress syndrome and myocarditis associated with hMPV in a child.
\end{abstract}

Keywords: Human metapneumovirus, myocarditis, child

\section{ÖZ}

Son yıllarda tanımlanan bir paramiksovirüs olan insan metapnömovirüsü (hMPV), küçük çocuklarda genellikle üst ve alt solunum yolu enfeksiyonları ile ilişkilendirilmiştir. hMPV ile ilişkili kardiyovasküler hastalık dahil olmak üzere şiddetli enfeksiyonlar özellikle yaşlı ve immün yetmezliği olan hastalarda bildirilmiştir. Literatürde çocuklarda miyokarditle seyreden bildirilmiş hMPV olgusu yoktu. Bu yazıda, hMPV'ye bağlı akut solunum sıkıntısı sendromu ve miyokardit birlikteliği bulunan nadir bir çocuk hasta sunulmuştur.

Anahtar Sözcükler: İnsan metapneumovirus, miyokardit, çocuk

\section{Introduction}

Human metapneumovirus (hMPV), a recently described paramyxovirus, is a non-segmented, negative-sense RNA virus (1). Since its discovery in the Netherlands in 2001, hMPV has been recognized as one of the most commonly causes of upper and lower respiratory tract infections in children (2). Although hMPV can infect adults and the elderly, the highest incidence of infection is among children under the age of 5 (3). It can cause various infectious diseases including rhinitis, bronchiolitis and pneumonia. The disease caused by hMPV is usually mild or moderate in severity and recovers spontaneously, but rarely may cause severe illnesses that requires admission to an intensive care unit. We report the case of a 2.5-month-old boy with acute respiratory distress syndrome and myocarditis secondary to the hMPV.

\section{Case Report}

A previously healthy 2.5 -month-old boy was hospitalized because of nonproductive cough lasting ten days. On the third day in this hospital, his clinical condition and breathing worsened and cardiomegaly was detected. He was intubated and referred to our department of pediatric intensive care unit for intensive care management and investigation of cardiomegaly. The patient was admitted to intensive care unit with a diagnosis of acute respiratory distress syndrome. His physical examination showed that his body temperature was $36.9^{\circ} \mathrm{C}$, oxygen saturation $96 \%$, blood pressure $76 / 48 \mathrm{~mm} \mathrm{Hg}$ and heart rate $160 / \mathrm{min}$. He had cutis marmorata. Capillary refill time was $>5$ seconds. Auscultation of the lungs revealed obvious bilateral thin rales and bilateral rhonchus. Abdominal examination revealed a liver enlargement 
of $5 \mathrm{~cm}$ below subcostal margin. His other examination findings were normal. Laboratory tests showed a white blood cell count of $11300 / \mu \mathrm{L}$ (normal range, 4000-10000), hemoglobin level of $8.56 \mathrm{~g} / \mathrm{dL}$, thrombocyte count of $225 \mathrm{bin} / \mu \mathrm{L}$, C-reactive protein level of $16 \mathrm{mg} / \mathrm{L}$ (normal range=0-5), and normal biochemistry values. His arterial blood gas results were as follows: $\mathrm{PH}=7.35, \mathrm{PCO}_{2=} 52, \mathrm{HCO}_{3}=22 \mathrm{mmol} / \mathrm{L}$, lactate $=5$, $\mathrm{O}_{2}$ saturation $=97 \%$. Chest X-ray $(\mathrm{CXR})$ showed cardiomegaly and bilateral diffuse opacities, suggesting bilateral pulmonary edema (Figure 1). Ventilation was started with high positive end-expiratory pressure (PEEP) on synchronized intermittent mandatory ventilation (SIMV) mode of mechanical ventilator. Blood, urine and tracheal aspirate cultures were taken and empirical antibiotic treatment with vancomycin and meropenem were started. Dopamine supplement was initiated for sepsis and secondary circulatory disorder. Electrocardiogram showed sinus tachycardia, widespread QRS voltage decrease, and ST elevation (Figure 2). Echocardiogram demonstrated a depressed ejection fraction of $36 \%$ with severely dilated left ventricle. Troponin-I level was $8 \mathrm{ng} / \mathrm{mL}$. Brain natriuretic peptide (BNP) level was $3200 \mathrm{pg} / \mathrm{mL}$. A dose of $2 \mathrm{~g} / \mathrm{kg}$ intravenous immunoglobulin (IVIG) was given to the patient who was diagnosed as having myocarditis according these findings. Intravenous (IV) diuretic and positive inotropic agents were started (furosemide $3 \mathrm{mg} \mathrm{IV}$, milrinone $0.5 \mathrm{mcg} / \mathrm{kg} / \mathrm{min}$ IV infusion). On the third day of his hospitalization, the patient in whom oxygenation did not recover carbon dioxide retention developed was taken to airway pressure release ventilation (APRV) mode. His echocardiographic examination showed that ejection fraction increased to $38 \%$. The referral hospital reported that respiratory viral reverse transcriptase polymerase chain reaction (PCR) performed in the nasopharyngeal swab sample with FilmArray ${ }^{\oplus}$ Multiplex PCR (BioFire, Biomerieux Diagnostics, France) was positive only for hMPV but negative for microorganisms most commonly causing pulmonary infection, including adenovirus, respiratory syncytial virus, influenza $\mathrm{A}$, influenza $\mathrm{B}$, parainfluenza, coronavirus, clamydia and mycoplasma. On the sixth day of his hospitalization, CXR findings also markedly improved. On the $10^{\text {th }}$ day of admission, the patient was extubated and his echocardiographic examination showed that ejection fraction increased to $48 \%$ and there was mild mitral regurgitation. Bilateral diffuse opacities and cardiomegaly improved on CXR (Figure 3). Dopamine infusion

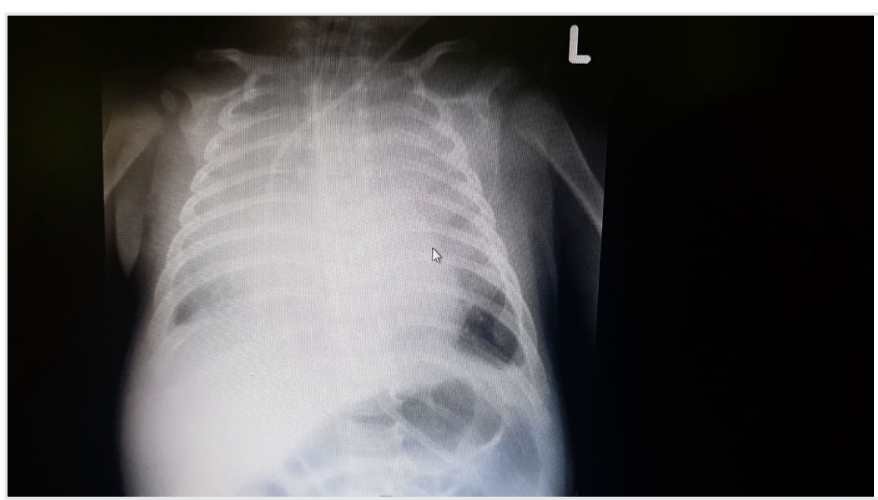

Figure 1. Chest X-ray shows cardiomegaly and bilateral diffuse opacities was stopped and digoxin was started. Blood, urine and tracheal aspirate cultures remained sterile. The antibiotic treatment was continued for 14 days. Finally, the patient was diagnosed as having hMPV infection complicated by ARDS and myocarditis. On the 16th day of admission, the patient recovered without any serious sequelae and he was discharged home on furosemide and digoxin.

\section{Discussion}

Human metapneumovirus (hMPV) was identified in 2001 by van den Hoogen et al. (1) from nasopharyngeal aspirates of children with respiratory tract infections. Since then, it has been reported worldwide as one of the most common causes of upper and lower respiratory tract infections (4). Clinical manifestations of hMPV infections are similar to that of respiratory syncytial virus and range from coryza to mild or moderate upper respiratory tract infections and severe lower respiratory tract infections requiring hospitalization (5). Mortality is rare and may occur in 5-10\% of children with hMPV infections who are admitted to the intensive care units. Although hMPV can cause infection in all age groups, studies have shown that mostly infants and young children are affected by hMPV infections (6). Human metapneumovirus is commonly associated with acute respiratory tract infections in children but it can affect different organ systems including

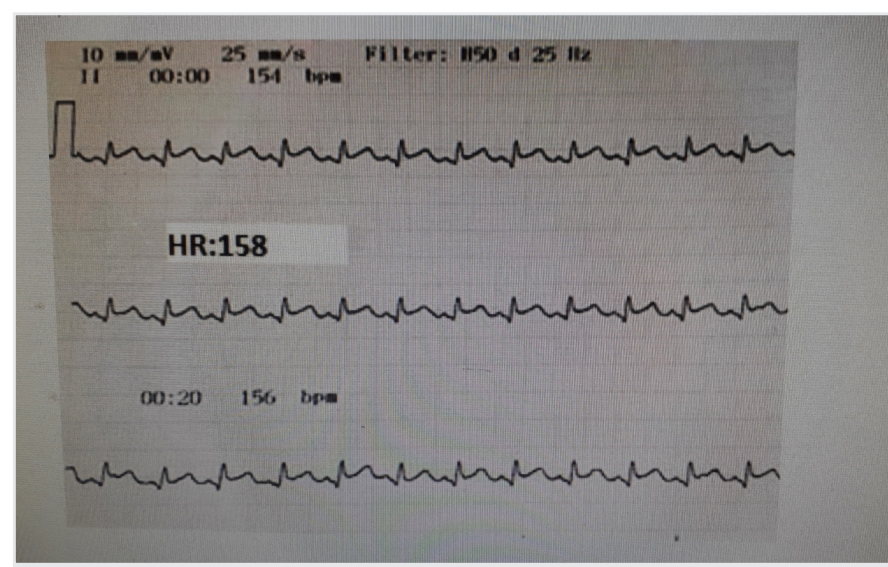

Figure 2. Electrocardiogram shows sinus tachycardia, widespread QRS voltage decrease, and ST elevation

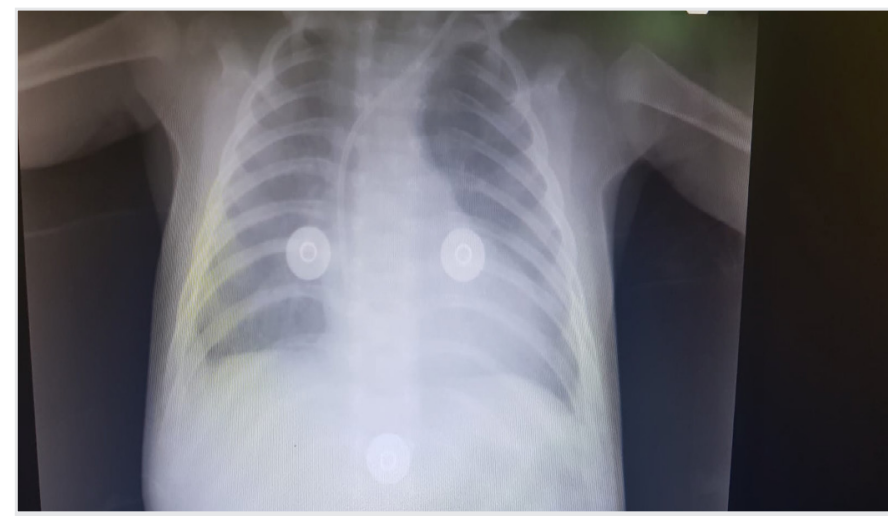

Figure 3 . On the $10^{\text {th }}$ day of hospitalization chest $X$-ray shows improved cardiomegaly and bilateral diffuse opacities 
cardiovascular system (7). Viral infections are the most commonly identified cause of myocarditis in children. These pathogens include enteroviruses, particularly Coxsackie B virus, adenovirus, parvovirus B19, human herpesvirus 6, cytomegalovirus, EpsteinBarr virus and influenza virus (8). Human metapneumovirus infections may be distinguished from the other respiratory tract infections due to more common accompanying cardiovascular diseases (9). In one of the few case reports, hMPV infection in a 25-year-old patient who was complicated by acute myocarditis was reported (10). A Korean pediatric study showed analysis of the medical records of 33 patients with myocarditis. Human MPV was one of the etiologic agents of acute myocarditis (11). We experienced a rare case of hMPV infection in an infant complicated by acute respiratory distress syndrome and myocarditis that resolved after intensive care management. Our patient presented with acute respiratoy failure and severe systolic dysfunction in the setting of a 10-day history of lower respiratory infection. Endomyocardial biopsy is the gold standard for diagnosis of myocarditis but it is an invasive test and may have complications. Therefore, it can be used in selected patients with unexplained diagnosis or those with cardiomyopathy who are unresponsive to treatment. Cardiovascular magnetic resonance (CMR) is a highly sensitive non-invasive imaging technique for the early diagnosis of myocarditis in children. CMR shows characteristic tissue changes such as edema, hyperemia, necrosis and fibrosis $(12,13)$. We made the diagnosis of myocarditis with clinical manifestations, elevated inflammatory markers, cardiac troponin I levels, and echocardiogram with reduced ejection fraction. Treatment of viral myocarditis is mainly supportive with unclear role of anti-inflammatory therapy, IVIG, steroids, and anti-viral therapy. Our patient was treated with high dose IVIG, intravenous diuretics and positive inotropic agents. In the present case, although a bacterial pathogen was not isolated, antibiotics were administered because of concerns regarding concomitant bacterial pneumonia.

\section{Conclusion}

Severe infections including cardiovascular diseases associated with hMPV are particularly reported in older and immune compromised patients. However, our patient was an infant. He responded well to high dose IVIG, intravenous diuretics and positive inotropic agents. He was discharged home after 16 days of intensive care hospitalization. Although hMPV is generally associated with acute respiratory tract infections in children, it should still be kept in mind that it can cause myocardial involvement.

\section{Ethics}

\section{Informed Consent:}

Peer-review: Externally peer reviewed.

\section{Authorship Contributions}

Concept: İ.E., K.T., Design: K.Y., B.V., İ.E., K.T., Data Collection or Processing: K.Y., İ.E., Analysis or Interpretation: K.Y., B.V., İ.E., Literature Search: K.Y., B.V., Writing: K.Y., İ.E.
Conflict of Interest: The authors declared no conflicts of interest with respect to the authorship and/or publication of this article.

Financial Disclosure: The authors received no financial support for the research and/or authorship of this article.

\section{References}

1. van den Hoogen BG, de Jong JC, Groen J, Kuiken T, de Groot $\mathrm{R}$, Fouchier RA, et al. A newly discovered human pneumovirus isolated from young children with respiratory tract disease. Nat Med 2001;7:719-24.

2. Kim CK, Choi J, Callaway Z, Kim HB, Chung JY, Koh YY, et al. Clinical and epidemiological comparison of human metapneumovirus and respiratory syncytial virus in seoul, Korea, 2003-2008. J Korean Med Sci 2010;25:342-7.

3. Principi N, Esposito S. Paediatric humanmeta pneumovirus infection: epidemiology, prevention and therapy. J Clin Virol 2014;59:141-7.

4. Garcia J, Sovero M, Kochel T, Laguna-Torres VA, Gamero ME, Gomez J, et al. Human metapneumovirus strains circulating in Latin America. Arch Virol 2012;157:563-8.

5. Heikkinen T, Osterback R, Peltola V, Jartti T, Vainionpää R. Human metapneumovirus infections in children. Emerg Infect Dis 2008;14:101-6.

6. Nascimento-Carvalho CM, Cardoso MR, Ruuskanen O, Lappalainen M. Sole infection by human metapneumovirus among children with radiographically diagnosed community-acquired pneumonia in a tropical region. Influenza Other Respir Viruses 2011;5:285-7.

7. Panda S, Mohakud NK, Pena L, Kumar S. Human metapneumovirus: review of an important respiratory pathogen. Int J Infect Dis 2014;25:45-52.

8. Tunuguntla H, Jeewa A, Denfield SW. Acute Myocarditis and Pericarditis in Children.

9. Pediatr Rev 2019;40:14-25.

10. Widmer K, Zhu Y, Williams JV, Griffin MR, Edwards KM, Talbot HK. Rates of hospitalizations for respiratory syncytial virus, human metapneumovirus, and influenza virus in older adults. J Infect Dis 2012;206:56-62.

11. Weinreich MA, Jabbar AY, Malguria N, Haley RW. NewOnset Myocarditis in an Immunocompetent Adult with Acute Metapneumovirus Infection. Case Rep Med 2015;2015:814269.

12. Kim HJ, Yoo GH, Kil HR. Clinical outcome of acute myocarditis in children according to treatment modalities. Korean J Pediatr 2010;53:745-52.

13. Martinez- Villar M, Gran F, Sabaté-Rotés A, Tello-Montoliu A, Castellote A, Figueras-Coll M, et al. Acute Myocarditis with Infarctlike Presentation in a Pediatric Population: Role of CardiovascularMagnetic Resonance. Pediatr Cardiol 2018;39:51-6.

14. Lv J, Han B, Wang C, Wang J, Jiang D, Zhao L, et al. The Clinical Features of Children With Acute Fulminant Myocarditis and the Diagnostic and Follow-Up Value of Cardiovascular Magnetic Resonance. Front Pediatr 2019;7:388. 